\title{
O NOVO PADRÃO DE DADOS HIDROGRAFICOS (S-100)
}

CMG Marcelo REIS da Silva, Centro de Hidrografia da Marinha do Brasil (CHM)

\section{Resumo}

A palestra tem como propósito apresentar os desafios do futuro para o qual o mundo hidrográfico está caminhando, com um nível de exigência e complexidade acrescido, em especial nos aspectos relacionados com a tecnologia da informação, mas que irá proporcionar um incremento significativo para a segurança da navegação. Tal desafio está relacionado com o desenvolvimento do novo padrão de dados S-100, pela Organização Hidrográfica Internacional $(\mathrm{OHI})$, através do esforço realizado pelos Grupos de Trabalho dos seus Estados Membros. O roteiro da apresentação traz breve noticia sobre a $6^{a}$ Edição da Publicação S-44 da OHI, que incorpora alterações importantes no padrão de coleta de dados hidrográficos, além da abordagem sobre as perspectivas do novo padrão de dados S-100. A nova edição da S-44 apresenta, pela primeira vez, especificações para LH não voltados para a segurança da navegação, por meio de Matriz de Especificações, além de acrescentar também, novos padrões mínimos de coleta de dados, independência de tecnologias e uma nova Ordem de Levantamentos Hidrográficos, a "Ordem Exclusiva", que prevê a identificação de feições no fundo de até $0,5 \mathrm{~m}$, com as necessárias limitações de incertezas vertical e horizontal. Tais inovações irão contribuir diretamente para o desenvolvimento do novo Padrão de Dados S-100, que também será aprsentado em seus aspectos relevantes, culminando com a importância desse novo padrão de dados no processo de implementação do conceito de E-Navigation (Navegação Aprimorada) bem como, na sua influência direta para viabilizar a utilização de Embarcações Autônomas. Por fim, a apresentação será concluida com algumas considerações finais, que sintetizarão o tema abordado. 